\section{6 OPEN ACCESS}

\title{
Psychoactive substance use by truck drivers: a systematic review
}

\author{
Edmarlon Girotto, ${ }^{1,2}$ Arthur Eumann Mesas, ${ }^{2,3}$ Selma Maffei de Andrade, ${ }^{2,3}$ \\ Marcela Maria Birolim²
}

- Additional material is published online only. To view please visit the journal online (http://dx.doi.org/10.1136/ oemed-2013-101452).

${ }^{1}$ Department of Pharmaceutical Sciences, Universidade Estadual de Londrina (UEL), Londrina,

Paraná, Brazil

${ }^{2}$ Postgraduate Program in Public Health, Universidade Estadual de Londrina (UEL), Londrina, Paraná, Brazil ${ }^{3}$ Department of Public Health, Universidade Estadual de Londrina (UEL), Londrina, Paraná, Brazil

\section{Correspondence to} Professor Edmarlon Girotto, Department of Pharmaceutical Sciences, Universidade Estadual de Londrina, Robert Koch Avenue, 60, Londrina, Paraná 86038-350, Brazil; eddieuel@yahoo.com.br

Received 15 February 2013 Revised 29 July 2013 Accepted 6 August 2013 Published Online First 21 October 2013

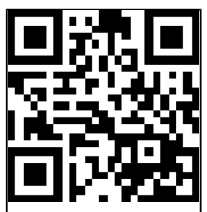

Open Access Scan to access mo free content

\section{Linked}

- http://dx.doi.org/10.1136/ oemed-2013-101791

\begin{tabular}{l}
\hline To cite: Girotto E, \\
Mesas AE, de Andrade SM, \\
et al. Occup Environ Med \\
2014;71:71-76.
\end{tabular}

\section{ABSTRACT}

The aim of this study was to summarise the scientific evidence on the prevalence of psychoactive substance use and on the factors associated with their intake among truck drivers. A systematic review was performed in the databases PubMed, Scientific Electronic Library Online, Latin American and Caribbean Health Sciences, and Cochrane and 36 cross-sectional studies were identified with quantitative results about the use of psychoactive substances by truck drivers. Out of these, 28 were carried out in countries with large land areas and 23 obtained their information through self-reporting. The most frequently studied substances were alcohol $(n=25)$, amphetamines $(n=17)$, marijuana $(n=16)$ and cocaine $(n=13)$. The prevalence of the use of these substances greatly varied: alcohol $(0.1-91.0 \%)$; amphetamines $(0.2-82.5 \%)$, marijuana $(0.2-29.9 \%)$, cocaine $(0.1-8.3 \%)$. The frequency of substance use was lower in studies that investigated the presence of these substances in biological samples than in those based on self-reported use. In 12 studies that evaluated factors associated with the intake of psychoactive substances, the following stood out: younger age, higher income, longer trips, alcohol consumption, driving in the night shift, travelling interstate routes, long or short sleep, fewer hours of rest, little experience of the driver, connection with small and medium sized companies, income below levels determined by labour agreements, productivity-based earnings and prior involvement in accidents. The frequency of psychoactive substance use by truck drivers seems to be high, although that greatly varies according to the type of substance and the method of collecting the information. The use of these substances was mainly associated with indicators of poor working conditions.

\section{INTRODUCTION}

Road transportation of goods drives the economic development in several countries, ${ }^{1}{ }^{2}$ especially in those with large territories and insufficient or inadequate railroad transport. Truck drivers are the main agents in this transportation system ${ }^{3}$ and their activity has unique features regarding work organisation, such as goals and short deadlines to achieve them, and also strenuous working hours. ${ }^{4}$

These drivers are subjected to countless factors that influence their professional practice, among which the intake of psychoactive substances stands out, ${ }^{56}$ used for reducing sleepiness during the trips and increasing willingness for work and socialisation. However, the use of these substances may cause harmful effects to the individual and to society. Amphetamines, when used to aid in sleepiness reduction, may cause agitation, tachycardia,

\section{What this paper adds}

- There are still few studies on the prevalence of psychoactive substance use by truck drivers.

- The prevalence is higher when information is obtained by self-report in comparison to biological samples.

- Individual characteristics were mainly associated with alcohol consumption while poor working conditions were mostly associated with amphetamine intake.

- It is recommended that future studies use standardised measurements that allow them to be properly compared, including meta-analyses to estimate joint association measures.

vertigo and hallucinations, besides altering the body's perceptions and reactions, thus raising the risk of traffic accidents. ${ }^{7-9}$

Despite the relevance of the subject, both socially and economically and also in the workers' health, the currently available evidence on the use of psychoactive substances by truck drivers consists of localised studies in specific contexts of each place studied. Considering that the analysis of individual studies provides little knowledge for elaborating measures to address the problem, this systematic review aimed to summarise the scientific evidence on the prevalence of psychoactive substance use and the factors associated with this intake among truck drivers.

\section{METHODOLOGY}

A systematic review was performed on the studies about the intake of psychoactive substances by truck drivers. Studies were selected if they were original and with quantitative results specifically on the use of psychoactive substances by truck drivers. No restrictions were made regarding language and year of publication. The recommendations of the Preferred Reporting Items of Systematic Reviews and Meta-Analyses ${ }^{10}$ were followed when applicable.

The studies were identified by consulting the databases PubMed, Scientific Electronic Library Online (SciELO), Latin American and Caribbean Health Sciences (LILACS) and Cochrane until the 30 April 2013. The PubMed search was carried out by combining the following keywords in the title or abstract: 'truck', 'lorry', 'lorries', 'heavy vehicle', 'heavy transport', 'motorist', 'driver', 'conductor', 'worker', 'job', 'professional', 'drug', 'stimulant', 'substance', 
'medicine', 'medication', 'psychoactive', 'amphetamine', 'cocaine', 'marijuana', 'crack', 'alcohol' and 'caffeine' (the search strategy can be found in the online supplemental material). For the SciELO and LILACS database searches, the terms 'truck', 'truck drivers' or 'load transport' were used, while in the Cochrane database the studies selected included the terms 'truck', 'lorry', 'lorries', 'heavy vehicle' or 'heavy transport'. The search strategy was based on language and syntax adequate to each database.

After the initial selection, studies whose titles clearly indicated they were not related to the subject were discarded. In a second step, the analysis of the abstracts made it possible to exclude other studies. During these steps, the review papers were kept. The remaining publications were obtained and analysed thoroughly. Moreover, their references were examined so that other papers could be located that had not been identified through the search strategy employed. After this process, the studies that fit the previously defined inclusion criteria were kept.

The whole article selection and review process was carried out independently by two researchers, who cross-checked their results in each of the steps and settled the discrepancies through consensus. A third researcher was consulted in case of disagreement. To analyse the selected studies, four tables were produced. The first table contains the general characteristics of each study; the second and third list the main descriptive results; and the fourth presents the studies that assessed factors associated with the intake of psychoactive substances.

\section{RESULTS}

The search resulted in 367 studies, excluding those duplicated and including the references of the articles consulted. After exclusions by the title or abstract, 65 studies were selected for complete reading. Out of these, 34 were included. $^{5-8} 11-40$ The reasons for excluding 31 papers are specified in figure 1 . The reading of these 34 papers identified 36 studies, since two papers presented results from two independent studies. ${ }^{15} 25$

Most studies were carried out in countries with large land areas, Brazil $(n=13)$, the USA $(n=10)$ and Australia $(n=4)$ being those with the highest number of investigations. Most papers were published starting in the year $2000(n=30)$ and involved samples below 500 subjects $(n=21), 7$ of which had less than 200 . About $70 \%$ of the studies only researched male drivers.

Out of the 36 studies analysed, 6 also investigated drivers of other motor vehicles. ${ }^{16} 22343537$ However, the results distinguished between the types of drivers, allowing truck drivers to be evaluated separately.

The method of data collection varied and included surveys at truck stops $(n=16)$, at events promoted for truckers $(n=4)$, with members of trucker associations $(n=3)$, analyses of biological samples from traffic accident victims $(n=4)$, with employees of a shipping company $(n=1)$, and other non-identified sources $(n=8)$. Among the inclusion criteria for the sample, drivers who drove long routes $(n=5)$ and vehicle characteristics $(n=7)$ were the most common. Nineteen studies did not have inclusion criteria for truck drivers (see table $1 \mathrm{~S}$ in online supplemental material).

Among the 36 investigations, 21 assessed the intake of substances only through truckers' self-reporting, 13 only through biological samples and two through both. ${ }^{36} 38$ Out of the 15 studies with biological samples, four used forensic data. ${ }^{8} 16{ }^{24}$ Snowden et $a l^{24}$ and Gates et al ${ }^{40}$ evaluated 71606 and 10190 results from biological samples, respectively. The

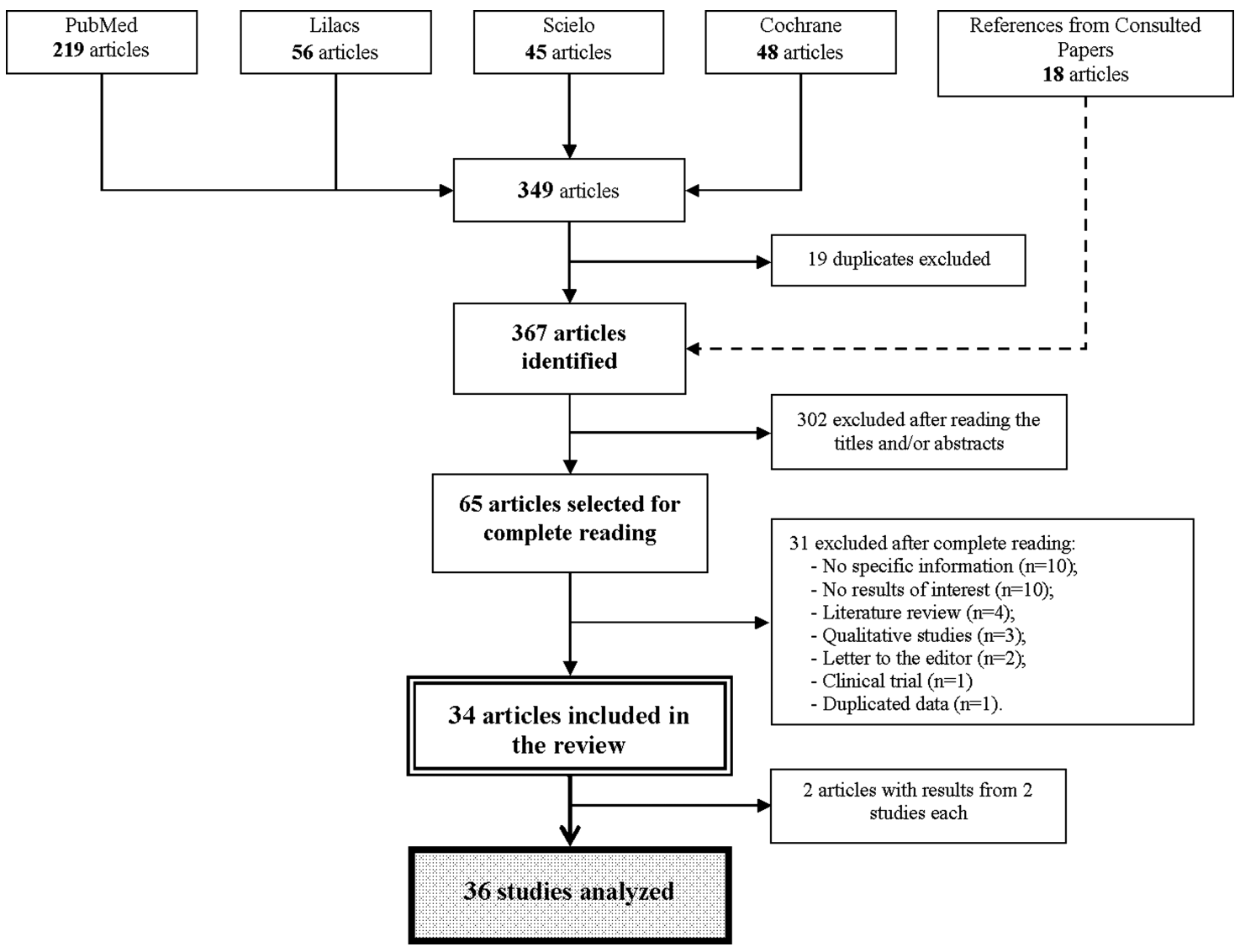

Figure 1 Flow chart for selecting papers. 
Table 1 Description of the studies on self-reported psychoactive substance use by truck drivers

\begin{tabular}{|c|c|c|}
\hline Study & Alcohol & Other substances \\
\hline Guinn $^{11}$ & NA & Drug use while trucking: $80.4 \%$ \\
\hline Korelitz et al ${ }^{13}$ & $59.2 \%$ (current) & NA \\
\hline $\begin{array}{l}\text { Mabbott and } \\
\text { Hartley }^{14}\end{array}$ & NA & $\begin{array}{l}\text { Illicit and prescribed stimulant: } \\
8.9 \% \\
\text { Illicit or prescribed stimulant: } \\
11.9 \% \\
\text { Over-the-counter stimulants: } 6.8 \%\end{array}$ \\
\hline Yildirim $^{18}$ & NA & Gripin: $65.0 \%$ \\
\hline Souza et al ${ }^{19}$ & $50.9 \%$ (current) & $\begin{array}{l}\text { Amphetamine: } 11.1 \% \\
\text { Caffeine: } 95.6 \%\end{array}$ \\
\hline Moreno et $a l^{20}$ & $51.1 \%$ (current) & NA \\
\hline Domingos et $a l^{21}$ & $\begin{array}{l}72.0 \% \text { (last } \\
12 \text { months) }\end{array}$ & NA \\
\hline Nascimento et $a l^{5}$ & $91.0 \%$ (current) & Amphetamine: $66.0 \%$ \\
\hline Sakurai et $a l^{23}$ & $54.8 \%$ (current) & NA \\
\hline Williamson $^{25}$ & NA & Stimulant drug use: $44.0 \%$ \\
\hline Williamson $^{25}$ & NA & Stimulant drug use: $31.1 \%$ \\
\hline Gay Anderson et al ${ }^{26}$ & $\begin{array}{l}63.0 \% \text { (last } \\
12 \text { months) }\end{array}$ & NA \\
\hline Penteado et $a l^{27}$ & $43.5 \%$ (current) & $\begin{array}{l}\text { Stimulants: } 7.5 \% \\
\text { Coffee: } 85.75 \% \\
\text { Energy drinks: } 19.5 \% \\
\text { Illicit drugs: } 2.0 \%\end{array}$ \\
\hline Domingos et $a l^{28}$ & $\begin{array}{l}73.8 \% \text { (last } \\
12 \text { months) }\end{array}$ & NA \\
\hline Jora et $a l^{29}$ & $\begin{array}{l}71.1 \% \text { (last } \\
12 \text { months) }\end{array}$ & NA \\
\hline Masson et $a l^{30}$ & $74.0 \%$ (current) & Amphetamine: $70.0 \%$ \\
\hline Masson et $a l^{31}$ & $49.5 \%$ (current) & Use of psychoactive drugs: $54.2 \%$ \\
\hline Riva et $a \beta^{33}$ & $49.2 \%$ (current) & $\begin{array}{l}\text { Amphetamine: } 0.9 \% \\
\text { Marijuana: } 15.9 \% \\
\text { Cocaine: } 5.3 \%\end{array}$ \\
\hline Laraqui et $a l^{34}$ & $11.8 \%$ (current) & $\begin{array}{l}\text { Marijuana: } 12.0 \% \\
\text { Coffee: } 71.8 \% \\
\text { Psychotropic medicines: } 3.9 \%\end{array}$ \\
\hline Leyton et $a l^{36}$ & NA & Amphetamine: $16.6 \%$ \\
\hline Mir et $a l^{37}$ & 9.9\% (while driving) & Marijuana: $29.9 \%$ \\
\hline Knauth et $a \beta^{39}$ & $73.1 \%$ (current) & $\begin{array}{l}\text { Amphetamine: } 12.4 \% \\
\text { Caffeine: } 14.8 \% \\
\text { Guarana powder: } 2.7 \% \\
\text { Energy drinks: } 3.9 \% \\
\text { Cocaine: } 0.4 \%\end{array}$ \\
\hline Yonamine et $a /^{38}$ & $25.9 \%$ (previous day) & Drugs: $1.2 \%$ \\
\hline
\end{tabular}

main substances consumed or identified in the studies were alcohol $(n=25)$, amphetamines $(n=17)$, marijuana $(n=16)$ and cocaine $(n=13)$ (see table $1 S$ in online supplemental material).

Tables 1 and 2 describe the main results found in the studies. Among the 23 studies with self-reported information, alcohol was the most frequently reported substance $(n=18)$. Meanwhile, in the 15 studies with biological samples, analyses for identifying amphetamines, marijuana and cocaine were the most common.

The average frequency of self-reported alcohol consumption was $54.3 \%$, ranging from a minimum of $9.9 \%$ (Pakistan) $^{37}$ to a maximum of $91.0 \%$ (Brazil) $^{5}$ (table 1). The identification of alcohol in biological samples was, on average, 3.6\%, a minimum of $0.1 \%$ (Australia and Norway) 2235 and a maximum of $12.5 \%$ (USA) $^{8}$ (table 2).

The average frequency of self-reported amphetamine intake was $29.5 \%$, ranging from $0.9 \%$ (Italy) $^{33}$ to $70.0 \%$ (Brazil) $^{30}$ (table 1). Amphetamines in biological samples averaged $8.5 \%$, from a minimum of $0.2 \%$ (Norway) ${ }^{35}$ to a maximum of $82.5 \%$ (Thailand). ${ }^{12}$

Marijuana and cocaine self-reported intake had average frequencies of $19.3 \%$ and $2.9 \%$, respectively (table 1 ). In the biological samples, averages of $4.7 \%$ for marijuana and $1.8 \%$ for cocaine were found (table 2). Marijuana use ranged from $0.2 \%{ }^{32}$ to $29.9 \%,{ }^{37}$ while cocaine ranged from $0.1 \%{ }^{6}$ to $8.3 \% .^{8}$ Besides these substances, others were occasionally analysed, such as opioids, ${ }^{6} 815163233$ phentermine, ${ }^{714}$ codeine, ${ }^{835}$ caffeine-based medication, ${ }^{18}$ pure coffee, ${ }^{27} 34$ energy drinks, ${ }^{27}$ antihistamines, ${ }^{15}$ benzodiazepines, ${ }^{6} 16$ among others. Six studies examined only the intake of psychoactive substances in general, without specifying them. $^{11} 14252730$

Only 12 studies analysed factors associated with the intake of psychoactive substances, ${ }^{5} 11 \quad 14 \quad 1821232528 \quad 35 \quad 3639$ two of which were carried out with biological samples. ${ }^{35} 36$

Alcohol intake was associated with overweight and obesity in a Brazilian study, ${ }^{28}$ however in a Japanese study, it was associated with lower average body mass index.$^{23}$ Alcohol intake was also associated with younger age, ${ }^{23}$ smoking, ${ }^{23}$ high blood pressure, ${ }^{23}$ catholic religion, ${ }^{21}$ fewer hours of rest, ${ }^{5}$ involvement in accidents ${ }^{5}$ and sleep-disordered breathing. ${ }^{23}$ In Norway, Gjerde et al ${ }^{35}$ identified that alcohol intake was more frequent among foreign drivers (table 3). The study by Sakurai et $a l^{23}$ was the only one to use adjustment variables (age, smoking and collection site) when analysing factors associated with alcohol intake.

The use of amphetamines was associated with driving during the night shift and with longer time in the profession. ${ }^{5}$ Another study, ${ }^{39}$ the only one identified in this review that used multiple regression analysis to identify factors associated with the use of amphetamines, found that younger age, higher income, longer trips, and alcohol consumption were positively associated with self-reported amphetamine intake (table 3), even after controlling for socio-demographic characteristics and religion.

A study carried out in Turkey found a positive correlation between the intake of medication containing caffeine and more hours driving during the day, years at the wheel and degree of stumbling. ${ }^{18}$ Williamson ${ }^{25}$ found that, in Australia, the use of stimulating medication was associated with less driver experience, work in medium and small sized companies, income below levels defined by union agreements, productivity-based earnings and fatigue (table 3).

It was also observed that drug intake (drug types were not specified in the studies) was associated with age less than 35 years, ${ }^{35}{ }^{36}$ male sex, ${ }^{35}$ contraproductive behaviours (inadequate work, stealing merchandise, failure to report damage to goods transported), ${ }^{11}$ driving on interstate routes, ${ }^{14}$ and short or long sleep times (table 3 ).

\section{DISCUSSION}

Despite its importance to public health, the current review detected that there are still few studies on the prevalence of psychoactive substance use by truck drivers. Most of these studies were carried out in countries with large land areas, such as Brazil, the USA and Australia. This shows that there is greater interest in the subject in areas where road cargo is predominant, especially for long routes, due to a possible relation with the use of psychoactive substances. ${ }^{14}$

Most studies included a small number of respondents, which highlights the difficulty in identifying and approaching this population group because they usually do not have regular sites for resting, loading and unloading. ${ }^{41}$ Moreover, half of the studies defined inclusion criteria for selecting drivers. Therefore, the results are representative of specific subgroups and caution must 
Table 2 Main results of the studies on psychoactive substance use by truck drivers analysed in biological samples

\begin{tabular}{|c|c|c|c|c|c|}
\hline Study & Alcohol & $\begin{array}{l}\text { Amphetamine/ } \\
\text { methamphetamine }\end{array}$ & Cannabinoids & Cocaine metabolites & Other substances \\
\hline Lund et $a l^{7}$ & $0.6 \%$ & $2.2 \%$ & $14.8 \%$ & $2.2 \%$ & $\begin{array}{l}\text { Phenylpropanolamine/ephedrine/pseudoephedrine: } 12.0 \% \\
\text { Phentermine: } 3.2 \%\end{array}$ \\
\hline Mongkolsirichaikul et a $/^{12}$ & NA & $82.5 \%$ & NA & NA & NA \\
\hline Crouch et al ${ }^{8}$ & $12.5 \%$ & $7.1 \%$ & $12.5 \%$ & $8.3 \%$ & $\begin{array}{l}\text { Caffeine: } 32.7 \% \\
\text { Codeine: } 0.6 \% \\
\text { Ephedrine: } 4.2 \% \\
\text { Phenylpropanolamine: } 0.6 \% \\
\text { Pseudoephedrine: } 3.0 \%\end{array}$ \\
\hline Couper et all ${ }^{15}$ & $0.3 \%$ & $1.4 \%$ & $3.3 \%$ & $1.1 \%$ & $\begin{array}{l}\text { Caffeine: } 93.4 \% \\
\text { Ephedrine/pseudoephedrine: } 5.5 \% \\
\text { Phentermine: } 0.6 \% \\
\text { Opiates/opioids: } 2.2 \%\end{array}$ \\
\hline Couper et al/ ${ }^{15}$ & $2.2 \%$ & $2.0 \%$ & $5.0 \%$ & $1.1 \%$ & $\begin{array}{l}\text { Caffeine: } 94.1 \% \\
\text { Ephedrine/pseudoephedrine: } 6.7 \% \\
\text { Opiates/opioids: } 1.1 \% \\
\text { Phentermine: } 0.4 \%\end{array}$ \\
\hline Drummer et $a l^{16}$ & $8.6 \%$ & NA & $6.5 \%$ & NA & $\begin{array}{l}\text { Benzodiazepines: } 0.7 \% \\
\text { Opioids: } 0.7 \%\end{array}$ \\
\hline Silva et $a l^{17}$ & NA & $4.8 \%$ & $0.27 \%$ & $0.27 \%$ & NA \\
\hline Drummer et $a l^{22}$ & $0.1 \%$ & $1.4 \%$ & $2.5 \%$ & NA & NA \\
\hline Snowden et $a l^{24}$ & $3.3 \%$ & NA & NA & NA & NA \\
\hline Labat et $a l^{6}$ & $5.0 \%$ & $0.3 \%$ & $8.5 \%$ & $0.1 \%$ & $\begin{array}{l}\text { Benzodiazepines: } 0.4 \% \\
\text { Buprenorphine: } 1.8 \% \\
\text { Opiates: } 4.1 \% \\
\text { Methadone: } 0.5 \%\end{array}$ \\
\hline Mieczkowski ${ }^{32}$ & NA & $0.14 \% *$ & $\begin{array}{l}0.21 \% \dagger \\
0.35 \% *\end{array}$ & $\begin{array}{l}0.27 \% \dagger \\
2.12 \% *\end{array}$ & NA \\
\hline Gjerde et $a l^{35}$ & $0.1 \%$ & $0.2 \%$ & $0.7 \%$ & $0.8 \%$ & Codeine: $0.2 \%$ \\
\hline Leyton et al ${ }^{\beta 6}$ & NA & $6.0 \%$ & $1.1 \%$ & $2.2 \%$ & NA \\
\hline Gates et $a l^{40}$ & NA & $2.3 \%$ & NA & $0.7 \%$ & $\begin{array}{l}\text { Benzoylecgonine: } 0.6 \% \\
\text { Phentermine: } 0.1 \% \\
\text { Chlorphentermine: } 0.1 \%\end{array}$ \\
\hline Yonamine et $a l^{38}$ & $1.4 \%$ & $0.6 \%$ & $0.4 \%$ & $0.6 \%$ & NA \\
\hline
\end{tabular}

be used in extrapolating the results to the whole trucker community. ${ }^{42}$ Nevertheless, they provide an important overview of the psychoactive substance use profile of these professionals.

The prevalence in the intake of psychoactive substances varied greatly, possibly influenced by the methodologies used to obtain data and the different populations studied. The working conditions of these professionals may also be significantly different, such as loading and unloading wait times, the lack of return cargo and the conservation conditions of roads and fleets, ${ }^{4-46}$ which may stimulate a greater or lower intake of psychoactive substances at work.

Biological analyses identify the presence of alcohol and other substances only if they have been used hours or a few days prior to sample collection. ${ }^{47}$ Therefore, although biological analyses are more specific, they tend to underestimate the intake prevalence. However, self-reported information can include the use of substances a few minutes prior to the investigation and covers the whole professional life. This methodology is therefore more sensitive but is subject to biases such as memory limitations and, especially, withholding information due to the legal implications of using these substances, thus also underestimating the prevalence. Therefore, the prevalence in studies using biological samples or self-reported information must be analysed separately since the methods used to measure the outcomes, in this case, are not comparable.
Alcohol intake is legal in the countries where the studies were conducted. However, legislation normally forbids alcohol intake prior to or while driving motor vehicles. The Worldwide Brewing Alliance reports that the maximum blood ethanol concentration for professional drivers in the countries where the studies were carried out is as follows: Italy $0.5 \mathrm{~g} / \mathrm{L}$, the USA $0.4 \mathrm{~g} / \mathrm{L}$, Japan $0.3 \mathrm{~g} / \mathrm{L}$, and Australia, Brazil, France and Norway $0.2 \mathrm{~g} / \mathrm{L}$. ${ }^{48}$ These limits, which are related to cultural and oversight issues, partly explain differences in alcohol intake and driving behaviours.

The prevalence of other important psychoactive substances (amphetamines, cocaine and marijuana) also varied. The study carried out by Mongkolsirichaikul et al ${ }^{12}$ in Thailand stands out for identifying an intake of amphetamines in urine samples $(82.5 \%)$ well above the average compared with other studies using biological samples. According to these authors, the excessive work hours (around 20-22 h) and possible addiction may be the reasons for these high levels.

Self-reporting was a method less frequently used to measure the intake of substances such as amphetamines, marijuana and cocaine given the difficulty in obtaining such information through interviews, especially since these are illicit drugs. Development and validation of questionnaires for obtaining such information anonymously may help further studies that attempt to determine the intake of illicit psychoactive substances 
Table 3 Main factors associated with the intake of psychoactive substances by truck drivers

\begin{tabular}{|c|c|c|c|}
\hline \multirow[b]{2}{*}{ Factors associated } & \multicolumn{3}{|l|}{ Outcome } \\
\hline & Alcohol & Amphetamine & Psycho-stimulant drugs \\
\hline \multicolumn{4}{|l|}{ Personal characteristics } \\
\hline Younger age & Sakurai et $a l^{23 *}$ & $\begin{array}{l}\text { Knauth et } a l^{39} \dagger \\
\text { Leyton et } a l^{\beta 6}\end{array}$ & \\
\hline Alcohol consumption & & Knauth et $a l^{39} \dagger$ & \\
\hline Current smoker & Sakurai et $a l^{23 *}$ & & \\
\hline Lower mean values of body mass index & Sakurai et $a l^{23 *}$ & & \\
\hline Overweight and obesity & Domingos et $a l^{28}$ & & \\
\hline Hypertension and use of antihypertensive medication & Sakurai et $a l^{23 *}$ & & \\
\hline Sleep-disordered breathing & Sakurai et $a l^{23 *}$ & & \\
\hline Catholic religion & Domingos et $a l^{21}$ & & \\
\hline Foreign nationality & Gjerde et $a l^{35}$ & & \\
\hline \multicolumn{4}{|l|}{ Job characteristics } \\
\hline Road accidents & Nascimento et $a l^{5}$ & & \\
\hline Longer time in the occupation & & Nascimento et $a l^{5}$ & \\
\hline Less experienced driver & & & Williamson $^{25}$ \\
\hline Longer trips & & Knauth et $a l^{39} \dagger$ & \\
\hline Night-time travel & & Nascimento et $a l^{5}$ & \\
\hline Fewer hours of rest & Nascimento et $\left.\mathrm{a}\right|^{5}$ & & \\
\hline Higher income & & Knauth et $a l^{39} \dagger$ & \\
\hline Salary on a piece-rate pattern & & & Williamson $^{25}$ \\
\hline Salary less than the award rate & & & Williamson $^{25}$ \\
\hline Drivers employed by small or medium sized companies & & & Williamson ${ }^{25}$ \\
\hline Contraproductive behaviour & & & Guinn $^{11}$ \\
\hline Fatigue & & & Williamson ${ }^{25}$ \\
\hline
\end{tabular}

in a more reliable way, in addition to representing a simpler and less costly methodology.

Since surveys show a higher prevalence of the intake of psychoactive substances, they are probably more reliable for identifying factors associated with the intake of these substances. These factors included less resting time and working night shifts, ${ }^{5}$ possibly because the workers need to resort to strategies to keep awake, among which the intake of psychoactive substances stands out. Lower incomes and productivity-based earnings $^{25}$ were also associated with the use of these substances, which could be explained by the possible motivation of the drivers to increase their income. ${ }^{27} 30{ }^{31}$ In fact, a study conducted in Brazil found that truck drivers with higher incomes and engaged in longer trips were more prone to use amphetamines, probably to remain awake to face their unfavourable working conditions. ${ }^{39}$ The authors also highlight the higher vulnerability of these individuals to other diseases and the lack of policies that address improvements in their health and working conditions. ${ }^{39}$ The association between the use of amphetamines and the involvement in accidents ${ }^{5}$ confirms the risks of using these substances while driving a vehicle.

Unlike the stimulant substances such as amphetamines, alcohol intake was associated more with the drivers' individual characteristics and health conditions, suggesting that alcohol intake is more common in a social or leisure context. ${ }^{29} 49$ Thus, the harmful effects of alcohol go beyond a greater risk of traffic accidents in truck drivers as it is also related to their health conditions.

The small number of analytic studies exposes a gap in the knowledge in identifying cargo drivers more vulnerable to the intake of psychoactive substances. Studies on representative samples of this population that identify factors associated with the intake of these substances are important, including the use of adjustment variables when needed. Moreover, it is recommendable that future studies use standardised measurements that allow them to be properly compared, including carrying out meta-analyses to estimate joint association measures.

Psychoactive substances have been proved to impair driving and cause a greater risk of traffic accidents. ${ }^{50-52}$ Therefore, gas stations, trucker stops and companies that employ these professionals must be more closely observed regarding the sale and consumption of these substances. There is some evidence that well planned and well executed multicomponent programmes, when implemented along with community action efforts, are effective in reducing alcohol-derived traffic accidents, ${ }^{53}$ although no studies were found that were performed specifically in truck drivers. Likewise, regulations for truck drivers, such as suitable working hours and income more compatible with the profession, in addition to better working conditions such as roads and vehicles in good repair, would contribute to a reduction in accidents and the implications these have for individual truck drivers and public health. ${ }^{354}$

In summary, the intake of psychoactive substances by truck drivers is a relatively frequent occurrence, although the prevalence varies according to the place and methodology employed. Furthermore, intake seems to be higher when working conditions are poor and can have a direct impact on the health of individual truck drivers and society as a whole due to the increase in traffic accidents. Although from a scientific standpoint the knowledge on the use of psychoactive substances by these professionals still needs to be broadened, the available evidence is more than enough to justify facing and addressing the problem. Well planned and well executed studies are crucial for assessing the effectiveness of strategies for reducing psychoactive 
substance use by truck drivers before or while driving, in addition to improving their working conditions.Acknowledgements The authors thank the National Council for Scientific and Technological Development $(\mathrm{CNPq})$ for granting a research productivity bursary.

Contributors E Girotto and M M Birolim participated in the conception of the article, search and interpretation of data, drafting the article and final approval of the version to be published. A E Mesas and S M Andrade contributed to the conception of the article, revising it critically for important intellectual content and final approval of the version to be published.

\section{Competing interests None.}

Provenance and peer review Not commissioned; externally peer reviewed.

Open Access This is an Open Access article distributed in accordance with the Creative Commons Attribution Non Commercial (CC BY-NC 3.0) license, which permits others to distribute, remix, adapt, build upon this work non-commercially, and license their derivative works on different terms, provided the original work is properly cited and the use is non-commercial. See: http://creativecommons.org/ licenses/by-nc/3.0/

\section{REFERENCES}

1 Toyoshima S, Ferreira MJ. Encadeamento do setor de transportes na economia brasileira. Planej Polít Públicas 2002:139-66.

2 Almeida LVC, Pignatti MG, Espinosa MM. Principais fatores associados à ocorrência de acidentes de trânsito na BR 163, Mato Grosso, Brasil, 2004. Cad Saúde Pública 2009;25:303-12.

3 Moreno CRC, Rotenberg L. Fatores determinantes da atividade dos motoristas de caminhão e repercussões à saúde: um olhar a partir da análise coletiva do trabalho. Rev Bras Saúde Ocup 2009;34:128-38.

4 Silva LG. 0 trabalho dos motoristas de caminhão: a relação entre atividade, vínculo empregatício e acidentes de trabalho [Dissertação]. São Paulo: Universidade de São Paulo, 2011

5 Nascimento EC, Nascimento E, Silva JP. Uso de álcool e anfetaminas entre caminhoneiros de estrada. Rev Saúde Pública 2007;41:290-3.

6 Labat L, Fontaine B, Delzenne $\mathrm{C}$, et al. Prevalence of psychoactive substances in truck drivers in the Nord-Pas-de-Calais region (France). Forensic Sci Int 2008;174:90-4.

7 Lund AK, Preusser DF, Blomberg RD, et al. Drug use by tractor-trailer drivers. J Forensic Sci 1988;33:648-61.

8 Crouch DJ, Birky MM, Gust SW, et al. The prevalence of drugs and alcohol in fatally injured truck drivers. J Forensic Sci 1993;38:1342-53.

9 Leyton V, Carvalho DG, Jesus MGS, et al. Uso de anfetamínicos por motoristas profissionais brasileiros: aspectos gerais. Saúde, Ética \& Justiça 2000-2002:5/7:32-6.

10 Liberati A, Altman DG, Tetzlaff J, et al. The PRISMA statement for reporting systematic reviews and meta-analyses of studies that evaluate healthcare interventions: explanation and elaboration. BMJ 2009;339:b2700.

11 Guinn B. Job satisfaction, counterproductive behavior and circumstantial drug use among long-distance truckers. J Psychoactive Drugs 1983;15:185-8.

12 Mongkolsirichaikul D, Mokkhavesa C, Ratanabanangkoon K. The incidence of amphetamine use among truck drivers from various regions of Thailand. J Med Assoc Thai 1988;71:471-4.

13 Korelitz JJ, Fernandez AA, Uyeda VJ, et al. Health habits and risk factors among truck drivers visiting a health booth during a trucker trade show. Am J Health Promot 1993:8:117-23.

14 Mabbott NA, Hartley LR. Patterns of stimulant drug use on Western Australian heavy transport routes. Transp Res, Part F Traffic Psychol Behav 1999:2:115-30.

15 Couper FJ, Pemberton $M$, Jarvis $A$, et al. Prevalence of drug use in commercial tractor-trailer drivers. J Forensic Sci 2002;47:562-7.

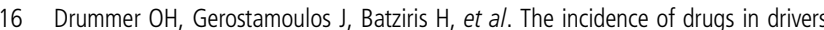
killed in Australian road traffic crashes. Forensic Sci Int 2003;134:154-62.

17 Silva OA, Greve JMD, Yonamine M, et al. Drug use by truck drivers in Brazil. Drugs 2003;10:135-9.

18 Yildirim RC. Caffeine consumption in drivers of heavy vehicles in Turkey. Public Health 2003;117:329-32.

19 Souza JC, Paiva T, Reimão R. Sleep habits, sleepiness and accidents among truck drivers. Arquivos de Neuro-Psiquiatria 2005;63:925-30.

20 Moreno CRC, Louzada FM, Teixeira LR, et al. Short sleep is associated with obesity among truck drivers. Chronobiol Int 2006:23:1295-303.

21 Domingos JBC, Pillon SC. 0 uso de álcool entre motoristas no interior do Estado de São Paulo. Rev Enferm UERJ 2007:15:393-9.

22 Drummer $\mathrm{OH}$, Gerostamoulos $\mathrm{D}, \mathrm{Chu} \mathrm{M}$, et al. Drugs in oral fluid in randomly selected drivers. Forensic Sci Int 2007:170:105-10.

23 Sakurai S, Cui R, Tanigawa T, et al. Alcohol consumption before sleep is associated with severity of sleep-disordered breathing among professional Japanese truck drivers. Alcohol Clin Exp Res 2007;31:2053-8.
24 Snowden CB, Miller TR, Waehrer GM, et al. Random alcohol testing reduced alcohol-involved fatal crashes of drivers of large trucks. I Stud Alcohol Drugs 2007:68:634-40.

25 Williamson A. Predictors of psychostimulant use by long-distance truck drivers. Am J Epidemiol 2007:166:1320-6.

26 Gay Anderson D, Riley P. Determining standards of care for substance abuse and alcohol use in long-haul truck drivers. Nurs Clin North Am 2008:43: 357-65.

27 Penteado RZ, Gonçalves CGO, Costa DD, et al. Trabalho e saúde em motoristas de caminhão no interior de São Paulo. Saúde Soc 2008:17:35-45.

28 Domingos JBC, Jora NP, Carvalho AMP, et al. Consumo de álcool, sobrepeso e obesidade entre caminhoneiros. Rev Enferm UERJ 2010;18:377-82.

29 Jora NP, Magalhães TR, Domingos JBC, et al. Campanha saúde na estrada: avaliação do padrão de consumo de álcool e estresse. Revista Eletrônica de Enfermagem 2010;12:37-46.

30 Masson VA, Monteiro MI. Vulnerabilidade à Doenças Sexualmente Transmissíveis/ AIDS e uso de drogas psicoativas por caminhoneiros. Rev Bras Enferm 2010;63:79-83.

31 Masson VA, Monteiro MI. Estilo de vida, aspectos de saúde e trabalho de motoristas de caminhão. Rev Bras Enferm 2010;63:533-40.

32 Mieczkowski T. Urinalysis and hair analysis for illicit drugs of driver applicants and drivers in the trucking industry. J Forensic Leg Med 2010;17:254-60.

33 Riva MM, Marchetti FA, Giupponi V, et al. [Health surveillance of truck drivers: it is not just a question of drugs. Description of a one-year experience]. Med Lav 2010;101:207-17

34 Laraqui S, Hossini OL, Tripodi D, et al. [Prevalence and risk factors of attention disorders of professional drivers in Morocco]. Sante Publique 2011:23:89-100.

35 Gjerde H, Christophersen AS, Normann PT, et al. Analysis of alcohol and drugs in oral fluid from truck drivers in Norway. Traffic Inj Prev 2012;13:43-8.

36 Leyton V, Sinagawa DM, Oliveira KC, et al. Amphetamine, cocaine and cannabinoids use among truck drivers on the roads in the State of Sao Paulo, Brazil. Forensic Sci Int 2012;215:25-7.

37 Mir MU, Khan I, Ahmed B, et al. Alcohol and marijuana use while driving-an unexpected crash risk in Pakistani commercial drivers: a cross-sectional survey. BMC Public Health 2012;12:145.

38 Yonamine M, Sanches LR, Paranhos BA, et al. Detecting alcohol and illicit drugs in oral fluid samples collected from truck drivers in the state of Sao Paulo, Brazil. Traffic Inj Prev 2013;14:127-31.

39 Knauth DR, Pilecco FB, Leal AF, et al. Staying awake: truck drivers' vulnerability in Rio Grande do Sul, Southern Brazil. Rev Saúde Pública 2012;46:886-93.

40 Gates J, Dubois S, Mullen N, et al. The influence of stimulants on truck driver crash responsibility in fatal crashes. Forensic Sci Int 2013;228:15-20.

41 Pinto RJC, Croce J, Kalil J, et al. Poeira de soja inalada e alergia respiratória no Brasil. Rev Bras Alergia Imunopatol 2007;30:198-203.

42 Osorio-de-Castro CGS, Paumgartten FJR, Silver LD. 0 uso de medicamentos na gravidez. Ciênc Saúde Coletiva 2004;9:987-96.

43 Pitta GBB, Castro AA. A pesquisa científica. J Vasc Bras 2006:5:243-44

44 Wanke P, Fleury PF. Transporte de cargas no Brasil: estudo exploratório das principais variávies relacionadas aos diferentes modais e às suas estruturas de custos. In: De Negri JA, Kubota LC.eds. Estrutura e dinâmica do setor de serviços no Brasil. Brasília: Instituto de Pesquisa Econômica Aplicada, 2006:409-64.

45 Bartholomeu DB, Caixeta Filho JV. Impactos econômicos e ambientais decorrentes do estado de conservação das rodovias brasileiras: um estudo de caso. Rev Econ Sociol Rural 2008:46:703-38.

46 Alves LC, Cruz CA. Análise da logística de distribuição do CPP. Rev Ciênc Geren 2008:12:139-58.

47 Ponce JC, Leyton V. Drogas ilícitas e trânsito: problema pouco discutido no Brasil. Rev Psiquiatr Clín 2008;35(Suppl 1):65-9.

48 Wordwide Brewing Alliance. Drinking and driving report. Recent trends and programmes, 2008:96p.

49 Abbey A, Smith MJ, Scott RO. The relationship between reasons for drinking alcohol and alcohol consumption: an interactional approach. Addict Behav 1993:18:659-70.

50 Bramness JG, Skurtveit S, Morland J. Clinical impairment of benzodiazepinesrelation between benzodiazepine concentrations and impairment in apprehended drivers. Drug Alcohol Depend 2002;68:131-41.

51 Gustavsen I, Morland J, Bramness JG. Impairment related to blood amphetamine and/or methamphetamine concentrations in suspected drugged drivers. Accid Anal Prev 2006;38:490-5.

52 Movig KL, Mathijssen MP, Nagel PH, et al. Psychoactive substance use and the risk of motor vehicle accidents. Accid Anal Prev 2004;36:631-6.

53 Shults RA, Elder RW, Nichols JL, et al. Effectiveness of multicomponent programs with community mobilization for reducing alcohol-impaired driving. Am J Prev Med 2009:37:360-71.

54 Neri M, Soares WL, Soares C. Health conditions in the cargo and passenger road transportation industry: a study based on the Brazilian National Sample Household Survey. Cad Saúde Pública 2005;21:1107-23. 